\title{
Musical Times
}

Review: Elijah

Author(s): Joseph Bennett

Review by: Joseph Bennett

Source: The Musical Times and Singing Class Circular, Vol. 37, No. 640 (Jun. 1, 1896), pp. 370-372

Published by: Musical Times Publications Ltd.

Stable URL: http://www.jstor.org/stable/3368021

Accessed: 24-01-2016 11:50 UTC

Your use of the JSTOR archive indicates your acceptance of the Terms \& Conditions of Use, available at http://www.jstor.org/page/ info/about/policies/terms.jsp

JSTOR is a not-for-profit service that helps scholars, researchers, and students discover, use, and build upon a wide range of content in a trusted digital archive. We use information technology and tools to increase productivity and facilitate new forms of scholarship. For more information about JSTOR, please contact support@jstor.org. 


\section{“ELIJAH."*}

THis addition to Mendelssohn literature hardly needed an introducer, but Sir George Grove so agreeably discharges what to him is a familiar duty that even the critical reader perceives nothing of the superfluous, although Sir George, in the most pleasant manner possible, cuts the ground from under his own feet by anticipating the remark with which I have just set out. It is well to possess the brief introduction, if only for assurance that its writer remains staunch to a great memory and conspicuous achievement while sympathising, as we all know he does, with whatever is good in the creations of the passing hour. "It has been the fashion," declares the musical Sage of Sydenham, "to speak of him (Mendelssohn) slightingly, nay, injuriously; but this will pass, and he needs no defence-certainly not when 'Elijah' is in question." Sir George could have used no apter word than "fashion" preliminary to the statement, "this will pass." All fashions, being more or less due to caprice, are doomed to pass, and the nearer their relation to caprice, the sooner comes extinction. It does not appear, however, that mere fickleness and whim have had greatly to do with the anti-Mendelssohn feeling which has prevailed, to a limited extent, in this country. It can be traced, I believe, to the action of abiding forces. Mendelssohn died fifty years ago, and the present generation, knowing nothing of his personal fascination, or the great wave of enthusiasm which carried his music to the highest pitch of favour, follows customary procedure in such cases, and is disposed to belittle the hero of its immediate predecessor, by way, perhaps, of asserting its own superior taste. Hence a certain reaction, than which nothing is more common in the world of art and literature-I was about to add, nothing more inevitable. The generation following that which Sebastian Bach adorned almost forgot him, but, doubtless, some George Grove of the period philosophically remarked, "This will pass," and he was right. In no case is the eclipse of a great man more than an eclipse. The intervening shadow moves off the shining face of the luminary, and we rejoice again in its light and beauty.

But I must not be betrayed into associating the name of Mendelssohn with the idea of eclipse. The master's enemies have, at the worst, achieved nothing beyond the equivalent of sun-spots.

The book now under review comes opportunely, and derives interest from, as well as gives interest to, the jubilee year of the great oratorio whose history it lays before us. But the volume, though it may benefit by, in no degree depends upon adventitious circumstances. It would have been as welcome ten

* "The History of Mendelssohn's Oratorio Elijah." " By F. G. Edwards. With an Introduction by Sir George Grove, C.B. London and New York: Novello, Ewer and Co. I8g6. years ago as it is now. There is nothing of the pièce d'occasion about it, and those amateurs who are wise enough to place the book upon their shelves will possess a good, solid contribution to the literature of a work which will ever remain a burning and a shining light in the firmament of music. That fifty years passed before the history of "Elijah" was taken in hand shows what a busy world we live in. It must have been generally known, or reasonably surmised, that much material bearing upon the subject remained to reward industrious research, and it was too apparent that Mendelssohn's contemporaries were rapidly passing away, taking precious information with them. Yet musical litterateurs, busy with other concerns, left the world in possession of mere fragments of knowledge till Mr. F. G. Edwards came upon the scene. For myself, I had long been conscious that a history of "Elijah " was needed, and often the impulse to write one came near to resolve. But what could a man immersed in daily journalism, with all his energies engrossed by current work-what could such as he do in furtherance of a task calling for extended, painstaking and patient research? I rejoice that Mr. Edwards has stepped in and accomplished, as well as need be, what was necessary to be done.

The " History of Elijah" is presented in five sections, respectively entitled "The Libretto," "Birmingham," "The English Translation," "The First Performance," "The Revised Oratorio." This is a convenient arrangement, well covering all the ground, and enabling the author to present his new material in due sequence and perfect order. The new material, it may now be pointed out, was obtained from three chief sources-first, from representatives of friends with whom the composer corresponded on the subject of his oratorio. It will suffice to mention such names as Klingemann, Moscheles, Moore (of Birmingham), and Schubring. Mrs. Victor Benecke, Mendelssohn's elder daughter, stands as the second source, that lady's contribution being several letters hitherto unknown, and a portrait of her father, taken in I835, which appears as a frontispiece to the book, and is now reproduced as a special supplement to the present issue of The Musical Times. In the third place Miss Mounsey, sister-in-law of William Bartholomew, provided our author with fourteen letters concerning the English translation of the German libretto. A facsimile of perhaps the most important of these communications forms a very interesting appendix to the volume.

I should be doing doubtful service to $\mathrm{Mr}$. Edwards if I seriously discounted the interest of the "History" by copious quotations, or even by too freely indicating the "plums" which readers will take pleasure in picking out for themselves. The facts in the book had better be left alone, save in so far as they serve 


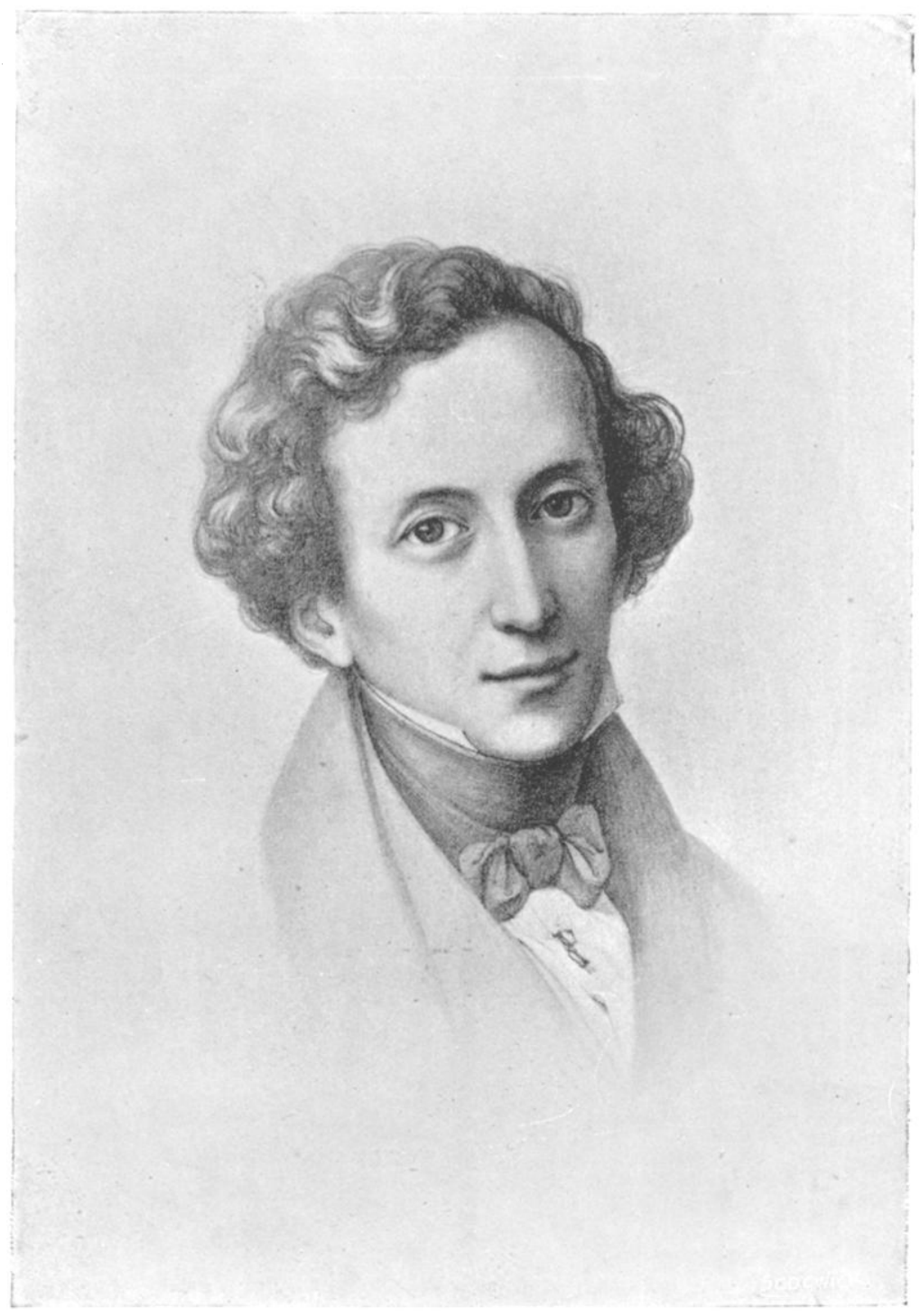

FELIX MENDELSSOHN-BARTHOLDY

At The Age of 26.

From a Pencil Drawing by Mücke, in the possession of Mrs. Victor Benecke. 
for such deductions as legitimately come within a reviewer's province.

A first conclusion is not merely suggested, but made absolutely clear by perusal of the opening section, "The Libretto." From Mendelssohn literature of older date than the present volume, we have long received an impression of the master's extreme fastidiousness, not only in relation to the music, but also the words of his works. That impression is now so deepened, and our view of Mendelssohn's comprehensive and minute criticisms is so clear as to make us all wonder, not that the master died so early, but that he lived so long. No human brain could stand such worry about verbal details in addition to the stress of great musical tasks. $\mathrm{He}$ appears to have been, at one time, unconscious of his peculiarity. Thus he writes to Klingemann concerning an "Elijah" book as though ready to accept, without question, anything sent: "I am satisfied with anything you do. You need not ask my advice, but just write out what you think best. Then I can compose it at once." The two men met in London and agreed upon a plan (scenario), but Klingemann did not feel encouraged to proceed farther. I have no doubt whatever that his colleague bewildered and alarmed him by the number and kind of his requirements. It was no longer a case of " "I am satisfied with anything you do." Pastor Schubring undertook the task abandoned by Klingemann, and Mr. Edwards, translating some of the published letters which passed between the reverend librettist and the composer, enables English readers to see the collaborateurs at work-and, as it turns out, toiling along on different tacks.

Mendelssohn, at that time, had dramatic impulses strong upon him. He wished, and intended to write an opera, when he could find a "book" that pleased him, and even in relation to his oratorio he was full of "appeal and rejoinder, question and answer, sudden interruptions," and what not, that goes to make up exciting stage business. But Pastor Schubring, gentle and pious soul, was the last man to provide materials for a sort of Scriptural opera. He did not want the public to be thrilled, but consoled and edified, as in some arias of "St. Paul," particularly "Be thou faithful unto death." Hence he wrote to Mendelssohn: "You must carefully consider whether this time you prefer to turn away from Church music (i.e., music which refreshes and consoles) and create a tone-picture after the manner of the Blocksberg-Cantata ('Walpurgis Night'). If not, we must diligently set to work to keep down the dramatic and raise the sacred element, and always aim at this." The good man wished to make of "Elijah" a kind of musical sermon. $\mathrm{He}$ would bring out prominently Elijah's significance with regard to the New Covenant. In another letter the Pastor refines upon his subject very much: "I have held to one point where the Lord Himself ought (to) or could speak to Elijah. It seemed to me that as Elijah appeared to Christ on the Mount of Transfiguration, so Christ might come to Elijah, transfigure him, and show him from afar the streams of peace which flow over the heavenly Canaan." It is easy to imagine the impatience with which Mendelssohn, in a dramatic humour, received such suggestions. "The personages should act and speak as if they were living beings," he exclaims, in one, for him, sharp outburst; " for Heaven's sake let them not be a musical picture, but a real world, such as you find in every chapter of the Old Testament, and the contemplative and pathetic element, which you desire, ought to be entirely conveyed to our understanding by the words and the mood of the acting personages." The writer then hints that he will go on with the book himself as far as possible, with which Schubring is quite content, and so the composer's second colleague drops away from his side. How the two men came together again six years later, when the Pastor gave his friend real assistance, everybody knows.

Mendelssohn's extreme fastidiousness and regard for detail appeár in a yet more striking light when we come to Mr. Edwards' chapter, "The English Translation." Here is a characteristic passage from one of his letters to Bartholomew : "Those words in the choruses which you or I may now or hereafter object to might, I hope, still be altered, in pencil or ink, in the parts, if already printed; for if an improvement can be made, it must never be omitted because the printing should be finished. A little more trouble will be amply repaid by a little improvement. And as for the solo parts, they must not be printed at all for the Festival, but only written out, and can only be printed together with the pianoforte arrangement, and after the performance. For these accordingly we have time, till then, to alter and improve. Pray let Mr. Buxton read all this." Mr. Buxton was "Ewer and Co.," and I wonder what he thought of it after reading, and whether he had prevision of much more to the same effect. The Bartholomew correspondence indicates an almost microscopic examination of the English text. From it, however, I cannot make extracts; the reader should procure the book and go through the whole for himself. A single sentence will show what he has to expect. With regard to a certain passage, the composer writes: "I propose . . . to slur from D to E flat, because I prefer to have the word af-fic-tion on the G flat." There is Mendelssohn, so to speak, in a nutshell, and the casual eye may now see that, if genius be the faculty of taking pains, the composer of "Elijah" was a very great genius indeed. This correspondence, moreover, makes quite clear to any in doubt on the point why Mendelssohn kept so many of his compositions in MS.-why, for example, 

even such a work as the "Italian" Symphony
was not published till after his death.

One or two points in the Bartholomew letters are of particular interest on other grounds, and may be touched upon here. It has long been known that the "Overture" to "Elijah" was an afterthought, and now it appears that the English translator suggested it. Bartholomew writes, as late as June 23, I846: "I hope you will have time to write an overture or introduction, unless you expressly design there shall be none." Mendelssohn answered : "My intention was to write no overture, but to begin directly with the curse. I thought it so energetic. But I will certainly think of what you say about an Introduction, although I am afraid it would be a difficult task, and do not know exactly what it should or could mean before that curse. And after it (I first thought to write the Overture after it) the chorus must immediately come in." He probably had in mind the opening of "Israel in Egypt," where an introductory recitative is directly followed by a chorus of complaint. Bartholomew kept to his point. He took counsel with Klingemann, and then wrote: "I . . . think it will be a new feature, and a fine one, to announce the curse, No. I. Then let an Introductory movement be played, expressive, descriptive, of the misery of famine." This is exactly what we now have, and the incident well exemplifies the old saying that two heads are better than one. Bartholomew was not so wise when he put it into Mendelssohn's mind that "O rest in the Lord" recalled "Auld Robin Gray," and thus nearly caused the loss to the oratorio--though he did not intend it-of the song which, more than any other, to use Schubring's words, "refreshes and consoles."

In "The Revised Oratorio" are some interesting letters, giving us a clear view of Mendelssohn once again at work with the microscope ; showing us incidentally, moreover, that the composer was quite cognisant of abnormal fastidiousness in his own case. Writing to Buxton, with reference to numerous changes in the chorus parts, he says: "I think I told you before that I was subject to this dreadful disease of altering as long as I did not feel my conscience quite at rest, and, therefore, I could not help it and you must bear it patiently." Some diseases, however dreadful, are salutary in the end, and we are all now thankful that Mendelssohn suffered from one of them, since comparison of the two versions makes one marvel how the composer could have seen his way to produce the first.

Mr. Edwards borrows a list of the principal alterations from Sir G. Grove's " Mendelssohn," in the well-known Dictionary,* adding observations of his own; but the principal value of the

* Sir G. Grove refers, in a foot-note, to my comparison of the two $*$ Sir G. Grove refers, in a foot-note, to my comparison of the two
scores, begun in Concordia and finished in THE MUSICAL TIMESscores, begun in Concordia and hnished in THE MUSCAL TrMEssome reason or other, passes it over in silence.-J. B. chapter lies in the letters, which materially augment our knowledge of "Elijah" at an interesting period in its long extended and elaborate creation.

Full details are given concerning the performance of the original version at Birmingham, and of the revised edition in London, together with many circumstances attendant upon both events. These, however, must be left to readers of the book, which, though not absolutely exhaustive of its subject, is, as already stated, a most valuable record of a great and, I am bold to think, undying art-work. It is important, also, for the light shed upon Mendelssohn's processes, and, obliquely, upon his mental and artistic constitution. Again, it enforces upon young composers the lesson that nothing should be considered as done while anything remains to do, and that long agonising towards perfection brings, like other virtues, its

own reward.

Joseph Bennett.

\section{THE BATON IN ENGLAND.}

THE baton, as a conducting-stick, did not come into general use in England until the third decade of the present century. Up to that time the conductor, in the present acceptance of the term, was almost unknown. There were, however, instances of a conductor who really did beat time. Samuel Wesley, in one of his lectures delivered in I827, said: "I remember that in the time of Dr. Boyce it was customary to mark the measure to the orchestra with a roll of parchment, or paper, in hand, and this usage is yet continued at St. Paul's Cathedral, at the musical performances for the Sons of the Clergy." Wesley goes on to say that the custom was not followed at the theatres and oratorios. It is, therefore, certain that the conductor, as a time-beater, was the exception and not the rule.

Handel "conducted" his operas and oratorios at the harpsichord or organ. At the Handel Commemoration of 1784 , held in Westminster Abbey, Joah Bates led his forces of 525 performers from the organ, and not with a baton. Haydn, who conducted his Salamon Symphonies at the Hanover Square Rooms in I79I, was announced thus: "Mr. Haydn will preside at the Harpsichord, and will Compose for every night a new piece of Music." During the first twenty years of the Philharmonic Society (I8I3-I833) there was no real conductor, except when foreign musicians like Spohr and Mendelssohn directed their own compositions. The programme of the Birmingham Musical Festival of 1829 (when Michael Costa, then a youth of nineteen, made his first appearance in England as a singer) records : "Conductor, Mr. Greatorex, who will preside at the Organ and Piano-Forte." Some idea of the then existing state of things may be 